\title{
Telhado Verde: sistema construtivo de maior isolação térmica
}

\author{
Green Roof: building system with greater thermal insulation \\ Green Roof: sistema constructivo con mayor aislamiento térmico
}

Recebido: 25/10/2021 | Revisado: 31/10/2021 | Aceito: 02/11/2021 | Publicado: 03/11/2021

\author{
Henrique Mendes da Silva \\ ORCID: https://orcid.org/0000-0001-6878-1622 \\ Universidade de Brasília, Brasil \\ E-mail: henriquemendes_bio@hotmail.com \\ Pâmela Raquel Souza e Silva \\ ORCID: https://orcid.org/0000-0001-5865-8575 \\ Centro Universitário de Patos de Minas, Brasil \\ E-mail: pamella_raquelvzt@hotmail.com
}

\begin{abstract}
Resumo
Este trabalho objetivou-se em fazer uma avaliação comparativa do conforto térmico dos ambientes de uma empresa de mineração do Noroeste de Minas Gerais, onde há presença do telhado verde com ambientes que não há presença desse telhado. Foi possível analisar e observar através de pesquisas e comparativos os resultados obtidos das temperaturas e umidade relativa que atuam no conforto térmico dos ambientes em atividades laborais. Neste trabalho foram realizadas medições in loco com equipamentos Dataloggers que possibilitaram todas as coletas de dados necessários para realização das comparações das temperaturas e umidades relativas internas e externas. Os resultados foram comparados ao literatura consultada que apresentaram conforto térmico satisfatório, mas que diante da NR17 o conforto térmico não foi atendido. Assim no final deste trabalho foi dada sugestão para melhoria do conforto térmico em relação à temperatura e umidade relativa dos ambientes em atividades laborais.
\end{abstract}

Palavras-chave: Telhado verde; Atividades laborais; Temperatura; Umidade relativa.

\begin{abstract}
This work aimed to make a comparative evaluation of the thermal comfort of environments in a mining company in the Northwest of Minas Gerais, where there is a green roof with environments where there is no such roof. It was possible to analyze and observe through research and comparative results obtained from temperatures and relative humidity that act on the thermal comfort of environments in work activities. In this work, measurements were performed in loco with Dataloggers equipment that allowed all the necessary data collection to carry out the comparisons of internal and external temperatures and relative humidity. The results were compared to the literature consulted, which showed satisfactory thermal comfort, but in view of NR17, thermal comfort was not met. Thus, at the end of this work, a suggestion was given to improve thermal comfort in relation to the temperature and relative humidity of the environments in work activities.
\end{abstract}

Keywords: Green roof; Work activities; Temperature; Relative humidity.

\section{Resumen}

Este trabajo tuvo como objetivo realizar una evaluación comparativa del confort térmico de ambientes en una empresa minera en el Noroeste de Minas Gerais, donde existe un techo verde con ambientes donde no existe dicho techo. Se logró analizar y observar a través de investigaciones y resultados comparativos obtenidos a partir de temperaturas y humedad relativa que actúan sobre el confort térmico de los ambientes en las actividades laborales. En este trabajo se realizaron mediciones in loco con equipos Dataloggers que permitieron toda la recolección de datos necesaria para realizar las comparaciones de temperaturas internas, externas y humedad relativa. Los resultados se compararon con la literatura consultada, que mostró un confort térmico satisfactorio, pero a la vista del NR17, no se alcanzó el confort térmico. Así, al final de este trabajo, se dio una sugerencia para mejorar el confort térmico en relación a la temperatura y humedad relativa de los ambientes en las actividades laborales.

Palabras clave: Cubierta vegetal; Actividades de trabajo; Temperatura; Humedad relativa.

\section{Introdução}

Os telhados verdes são uma fonte alternativa de diminuir as temperaturas do interior das edificações causadas pelas fortes, radiações solares, melhorar a qualidade do ar e restringir os gastos de energia (Morais, 2004).

O conforto térmico é a sensação de bem estar ligado à temperatura. É o equilíbrio entre a perda de calor produzido pelo corpo e o calor do ambiente. (Lanbeee, 2016) 
O conforto térmico, acústico e visual, segundo o site Lanbeee (2016) é essencial para uma boa qualidade de vida. Para garantir uma estrutura arquitetônica de boa qualidade é necessário adequar o projeto construtivo ao clima onde será introduzido e fazer uma boa escolha dos materiais, sendo assim capazes de reduzir o consumo de energia e oferecer condições satisfatórias aos usuários.

Segundo Mascaró (1985 p.17) “a correta resolução deste conjunto de fatores, ou seja de temperatura e humidade, não dependem só a concretização das condições mínimas de habitabilidade, mas também a otimização dos consumos de energia na edificação".

Perante a grande preocupação mundial a respeito do aquecimento global e economia de energia, este trabalho procura analisar o conforto térmico da edificação que possui telhado verde em relação aos seus locais de estudo.

O ponto principal desse trabalho será o estudo do conforto térmico, através de coletas de dados in loco.

Tal estudo justifica-se pela necessidade de conhecer as vantagens da utilização do sistema de construção de telhado verde, pois isso é fundamental para sua conservação, para uma forma de diminuição dos danos causados pela impermeabilização das cidades. Sendo importante também um estudo sobre sua potência como isolante térmico a fim de verificar sua eficácia quanto à diminuição dos gastos com aquecimento e resfriamento de ambientes.

O presente estudo tem como objetivo geral fazer uma análise comparativa da eficiência dos sistemas construtivos de telhado verde, quanto à sua capacidade de isolação térmica, diminuindo gastos com energia para aquecimento e resfriamento dos ambientes. Ainda com o objetivos específicos tem como intuito conceituar os principais tipos de telhado verde; analisar o conforto térmico em ambientes onde é exercido atividades laborais; analisar como o telhado verde pode interferir na climatização do ambiente construído; verificar o impacto socioeconômico para os usuários deste tipo de técnica construtiva; e apresentar as vantagens da construção de um telhado verde.

Portanto tal estudo é de suma importância, pois se trata de um estudo ímpar, devido à falta de estudos relacionados ao tema, o que irá proporcionar aos leitores um maior interesse na área, além de ampliar os conhecimentos de pesquisa em relação a este tema, fornecendo subsídio para uma maior atuação na área da docência.

\section{Referencial Teórico}

\subsection{Conforto ambiental}

O conforto ambiental refere-se em adequar os princípios físicos envolvidos e as necessidades do ambiente, que se dividem em temperatura, luz, acústica e visual. (Marta Oliveira, 2011)

De acordo com Herlemann (2012):

Atingir um desempenho ambiental satisfatório envolve um correto planejamento arquitetônico, diante das diferentes condições climáticas que influenciarão nas condições térmicas (temperatura, vento e umidade), na qualidade acústica (proteção de ruídos intrusivos, inteligibilidade do professor pelos alunos e vice-versa) e, ainda, nas condições ideais de visão e iluminação, natural ou artificial, proteção contra poluição e qualidade interna do ar, estabilidade estrutural da edificação, salubridade e higiene, segurança e outros. (Herlemann 2012 p. 92)

\subsection{Conforto térmico}

Conforto térmico pode ser definido de diversas formas, entretanto todas estas definições têm como intuito expressar quando um indivíduo está confortável termicamente em um determinado local. Segundo Ashrae (2004) o termo conforto térmico é uma condição física e psicológica que expressa à satisfação do homem com o ambiente, seja ela no ambiente externo ou interno. De acordo com Lamberts, Dutra \& Pereira (2004, p. 41): “Se existir um equilíbrio entre todas as trocas de calor sobre um corpo entre a temperatura da pele e sua transpiração e estes estiverem dento de certos limites, pode-se afirmar que o indivíduo apresenta conforto térmico". 
Sendo assim o conforto ambiental refere-se em adequar os princípios físicos envolvidos e as necessidades do ambiente, que se dividem em temperatura, luz, acústica e visual.

De acordo com isso Mascaró (1985) afirma que:

Os quatro fatores dinâmicos do clima - temperatura, unidade, movimento do ar e radiação - afetam a perda de calor no homem. Esses fatores climáticos não atuam isolados, mas conjuntamente. $\mathrm{O}$ efeito de sua ação conjunta sobre o indivíduo denomina-se Pressão Térmica. Quando o homem deixa de perder calor na mesma velocidade em que absorve, os resultados são, altamente desconfortáveis. (Mascaró, 1985, p. 16)

O isolamento térmico é decisivo pra diminuir as trocas térmicas entre o exterior e interior de uma construção. No caso do telhado verde é consequência de dois condicionantes: a absorvência dos raios solares pelos vegetais durante a fotossíntese e a medida da cobertura verde que funciona como uma manta isolante.

\subsection{Definição de telhado verde}

O sistema de telhado verde, pode ser chamado de jardim suspenso ou cobertura vegetal, é um sistema construtivo que se caracteriza por uma camada vegetal feita com diferentes tipos de vegetação. É construído em lajes ou até mesmo sobre telhados clássicos ou tradicionais e consiste em camadas de drenagem e impermeabilização, as quais recebem o tipo correto de solo e a vegetação indicada para cada projeto. Os telhados verdes tem a função de isolantes térmicos nas coberturas das edificações, além da estética. Para as cidades, estes desempenham importante papel como área vegetativa que, em larga escala, minimizam o efeito das ilhas de calor e melhoram a qualidade do ar em si. No Brasil, o sistema ainda não é muito utilizado e não tem normatização. Algumas cidades e Estados, como Porto Alegre, Santa Catarina e Guarulhos na grande São Paulo, têm instruções e até mesmo leis que incentivam a implementação das coberturas verdes em edificações públicas e privadas (Figura

1). (Corsini, 2011)

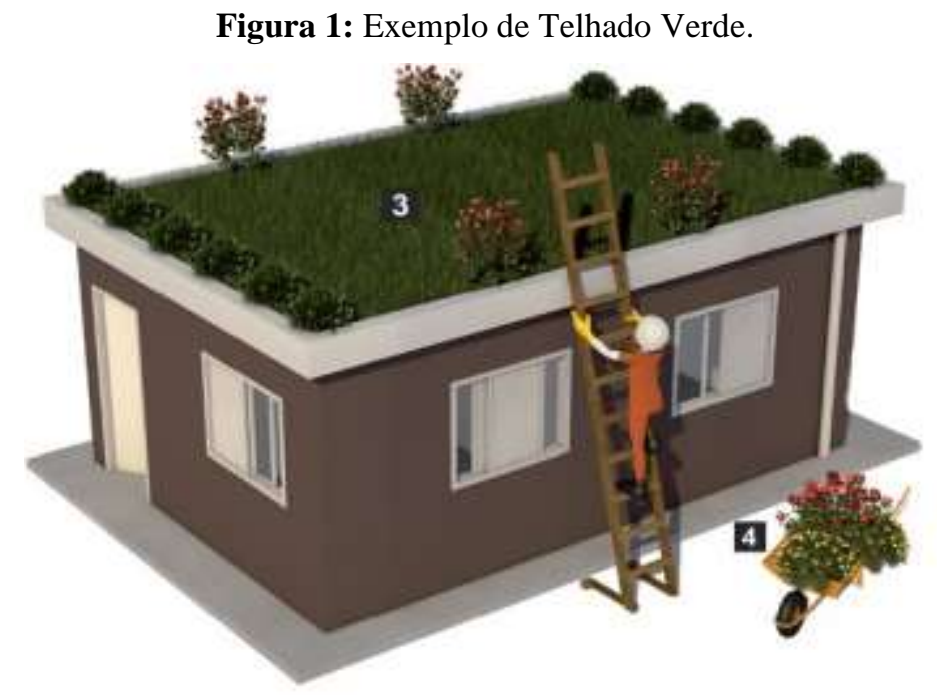

Fonte: Site Infraestrutura Urbana (2021).

Os telhados verdes ajudam em ter uma paisagem mais agradável, como exemplo, prédios que utilizam a área verde do telhado para lazer.

\subsection{Evolução histórica do telhado verde}

Em 600 a.c., tempo conhecido como Antiga Mesopotâmia, onde hoje é o atual Iraque, existiam várias construções que 
tinha jardins suspensos (Figura 2), que se chamavam Zigurates e o mais famoso era Etemenanki, na Babilônia, que tinha 91metros de altura e 91x91 metros na base. (Telhados Críticos, 2012)

Figura 2: Famosos "Jardins Suspensos da Babilônia".

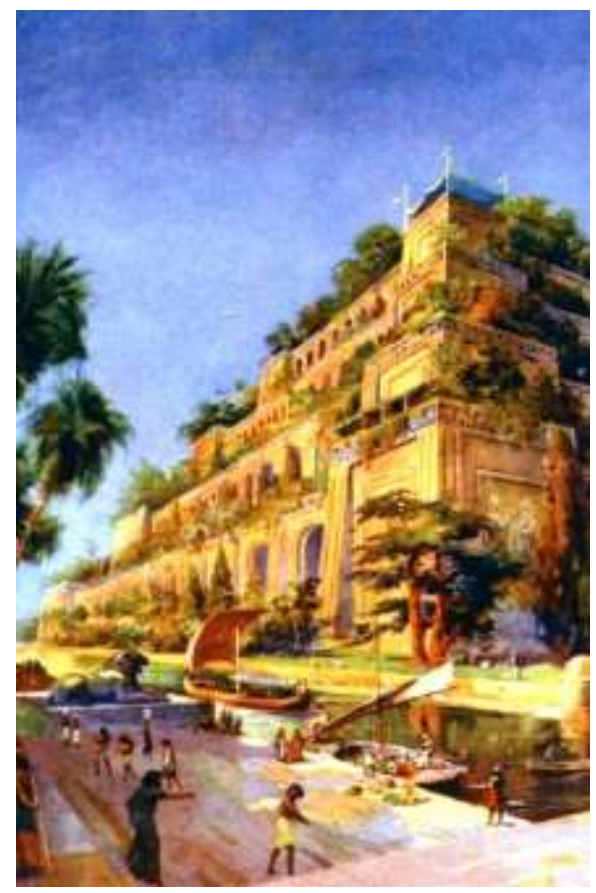

Fonte: Site - Info Escola (2021).

Os Jardins Suspensos da Babilônia (Figura 2), é uma das sete maravilhas do mundo, estes se localizavam no lado leste de Eufrates, por entre os palácios reais e as margens do rio (Discovery Channel, 2009)

Mais tarde, os telhados verdes foram levados para o Império Romano, onde cresciam árvores nas coberturas dos edifícios. No período renascentista na Itália, entre os séculos XVI e XVII, em algumas cidades da Espanha, no século XVIII na França (Figura 3 B e C), no século XIX na Escandinávia e nos Estados Unidos no século XX (Figura 3 C) (Araújo, 2007).

A Alemanha, nos anos 50, investiu em pesquisas científicas sobre o tema com o objetivo de conversação da água e energia por meio desse sistema construtivo.

Segundo Tomaz (2005) no Brasil, o primeiro telhado verde criado foi em 1936, no prédio do MEC (Ministério da Educação e Cultura) edificado por Roberto Burle Marx (Figura 3 D), no ano de 1988 foi construído o Banco Safra em São Paulo, em 1992 os jardins do Vale do Anhangabaú (Figura 3 E), projetado por Rosa Grená Kliass e Jamil Kfouri, além do edifício Matarazzo, atual sede da Prefeitura de São Paulo e antigo prédio do Banespa (Figura 3 F e 4).

Atualmente existem em empresas especializadas nesse tipo de construção, fazendo com que cada dia aumente mais a produção de telhados verdes em construções civis. 
Figura 3: Jardim Suspenso (A). Construção da Villa Savoye - França (B). Terraço jardim da Villa Savoye - França (C).

Telhado verde em edifício nos Estados Unidos (D), Terraço do MEC, em São Paulo, projetado por Roberto Burle Marx (E). Prédio da Prefeitura de São Paulo, visto do Vale do Anhangabaú (F).
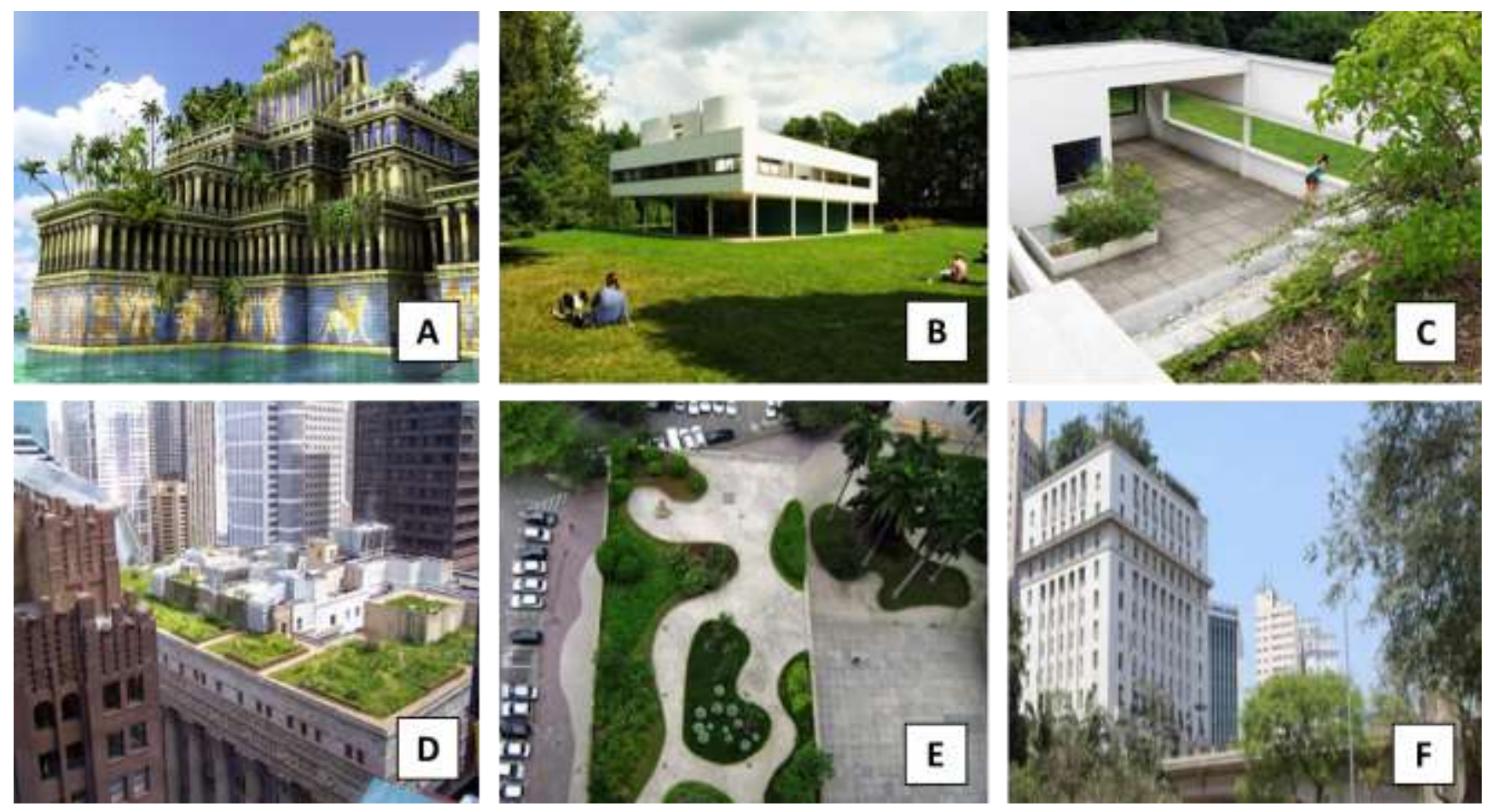

Fonte: Site - 7Log, 2021 (A). Blog - História e Arquitetura (2021) (B-E). José Cordeiro/SPTuris (2021) (F).

Figura 4: Edifício Matarazzo, atual sede da Prefeitura de São Paulo e antigo prédio do Banespa.

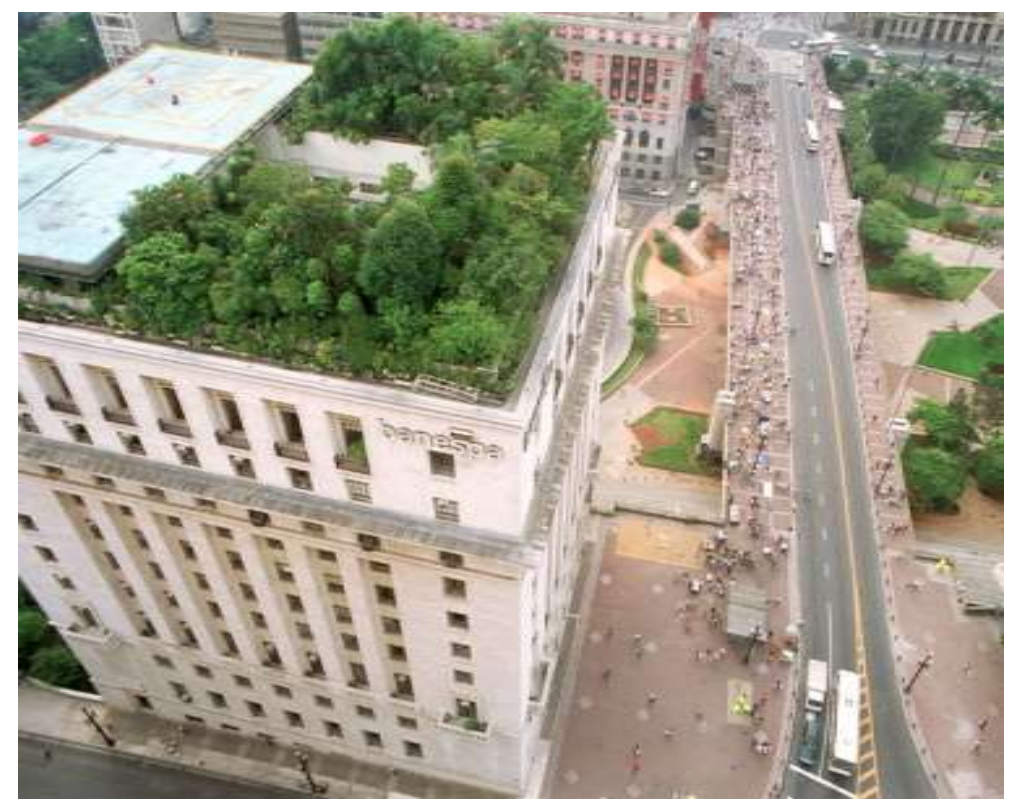

Fonte: Hélvio Romero/Estadão Conteúdo/Arquivo (2021).

\subsection{Legislação sobre o assunto}

Foi aprovada uma lei em Paris, a capital da França para que os prédios comerciais tenham telhados verdes ou placas solares. A intenção é reduzir as dependências das usinas nucleares que cobre uma demanda de 75\% de energia do país segundo os dados da World Nuclear Association (Figura 5). (Oro Mendes, 2015) 
Os telhados verdes fabricados com gramas ajudam a aumentar a umidade do ar, sendo uma grande e crescente contribuição em cidades secas e sem verde.

Entre suas principais vantagens, destaca-se que os telhados verdes retêm a água das chuvas e filtram partículas suspensas no ar, como fuligem. (Oro Mendes, 2015)

Figura 5: Telhados verdes em Paris.

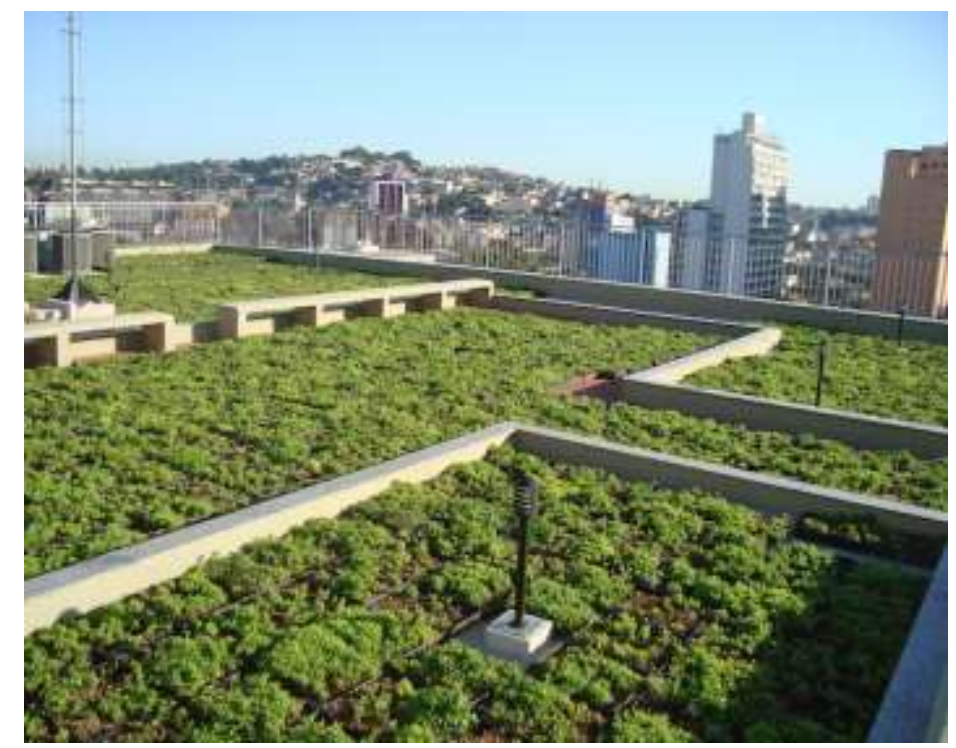

Fonte: Site Awebic (2021).

Ainda servem como ótimas sugestões para se fazer uma horta orgânica, por exemplo. Sendo possível utilizar o telhado como horta para todo o prédio, aumentando a qualidade na alimentação de todos da vizinhança. (Oro Mendes, 2015).

\subsection{Categorias de telhados verdes}

Em conformidade com a International Green Roof Association (INGRA), os telhados verdes podem ser classificados em três tipos: os Extensivos, Intensivos e os Semi-intensivo.

Os extensivos caracterizados por possuir baixa profundidade de substrato, sendo plantas de pequeno porte que necessitam de pouca manutenção devido ao seu lento e baixo crescimento. A altura da estrutura, somando a vegetação vai de 6 a $20 \mathrm{~cm}$ e o peso total fica entre $60 \mathrm{~kg} / \mathrm{m}^{2}$ a $150 \mathrm{~kg} / \mathrm{m}^{2}$. (Ingra, 2010)

Os intensivos são caracterizados por plantas de nível médio a grande, sua altura varia entre 15 a $40 \mathrm{~cm}$ com carga entre $180 \mathrm{~kg} / \mathrm{m}^{2}$ a $500 \mathrm{~kg} / \mathrm{m}^{2}$. (Ingra, 2010)

E o terceiro, o semi-intensivo, tem vegetação de porte mediano, tendo com altura total da estrutura 12 a $25 \mathrm{~cm}$, e carga variando de $120 \mathrm{~kg} / \mathrm{m}^{2}$ a $200 \mathrm{~kg} / \mathrm{m}^{2}$. (Figura 6). (Ingra, 2010) 
Figura 6: Ilustração esquemática dos diferentes tipos de telhados verde.

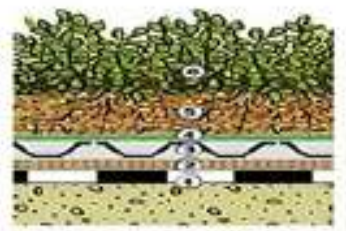

Sistema exiensivo

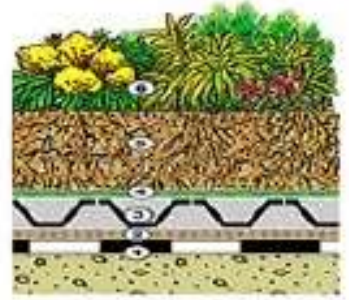

Sistema semi-extensivo

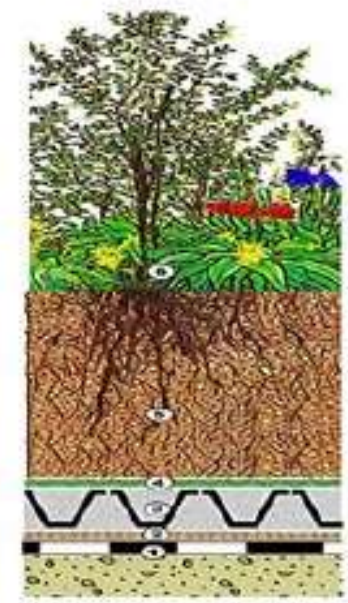

Sistema intensivo

Fonte: Adaptado de Green Roof Service LLC (2021).

\subsection{Técnicas de construção}

O telhado verde é aplicado diretamente sob a laje, para isso é necessário fazer da seguinte ordem:

- $\quad 1^{\circ}$ passo: Camada impermeabilizante: sua função é evitar infiltrações, geralmente são utilizadas mantas sintéticas (Figura 7).

Figura 7: Laje de concreto.

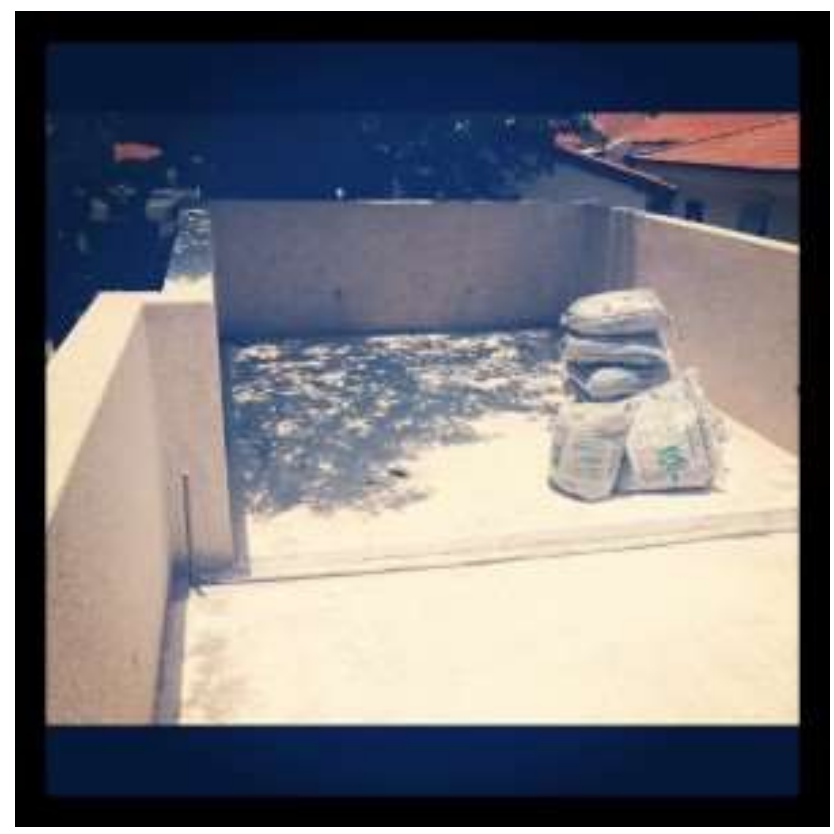

Fonte: Site Ecoeficientes - Especialistas em técnicas de Construção Sustentáveis (2021).

- $\quad 2^{\circ}$ passo: Camada drenante: o material utilizado pode ser brita, seixos, argila expandida ou manta drenante de poliestireno. Essa camada tem como objetivo servir como filtro e drenar a água (Figura 8 e Figura 9). 
Research, Society and Development, v. 10, n. 14, e341101422238, 2021

(CC BY 4.0) | ISSN 2525-3409 | DOI: http://dx.doi.org/10.33448/rsd-v10i14.22238

Figura 8: Manta Asfáltica.

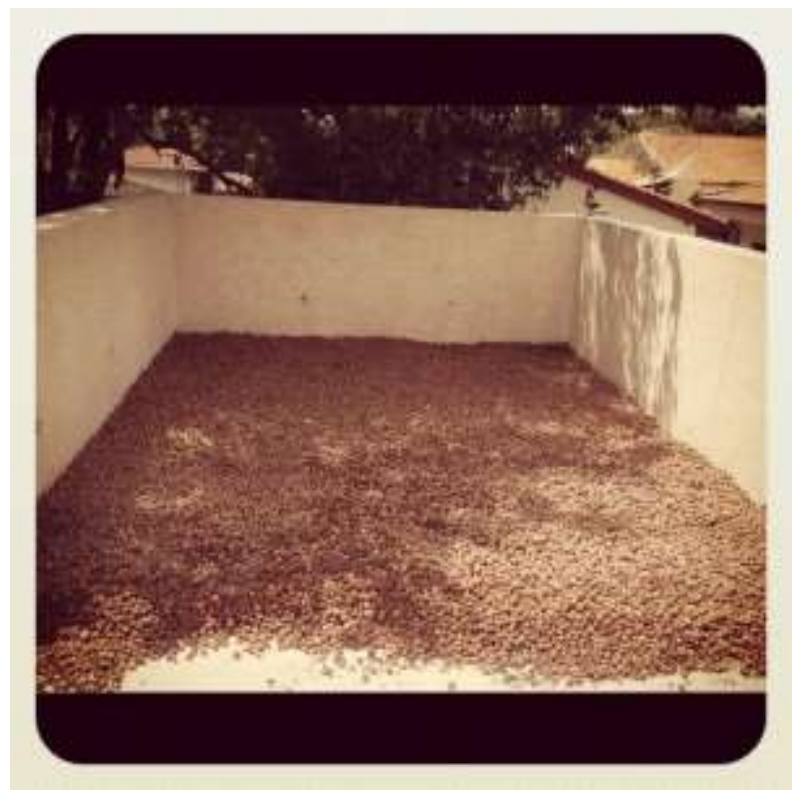

Fonte: Site Ecoeficientes - Especialistas em técnicas de Construção Sustentáveis (2021).

Figura 9: Manta Asfáltica (DrykoVedamanta, Poliéster, $4 \mathrm{~mm}, 10 \mathrm{~m}^{2}$ ) utilizada pela empresa.

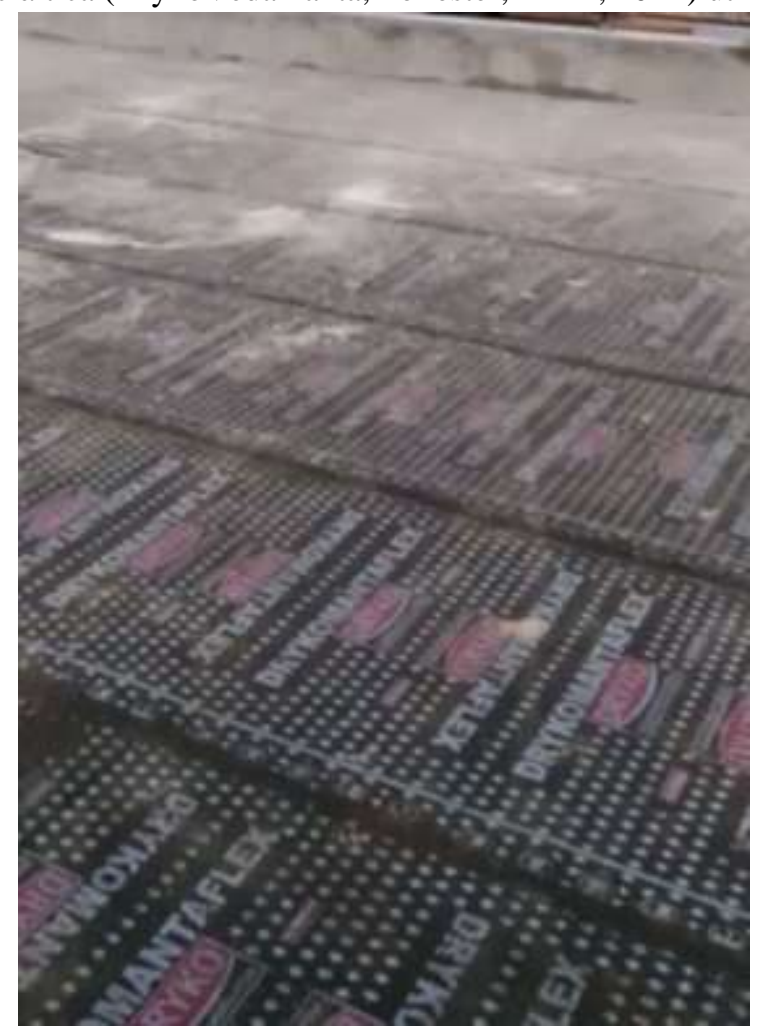

Fonte: Autores (2021).

- $\quad 3^{\circ}$ passo: Camada filtrante: é feita com o geotêxtil e serve para reter partículas (Figura 10). 
Figura 10: Camada Filtrante.

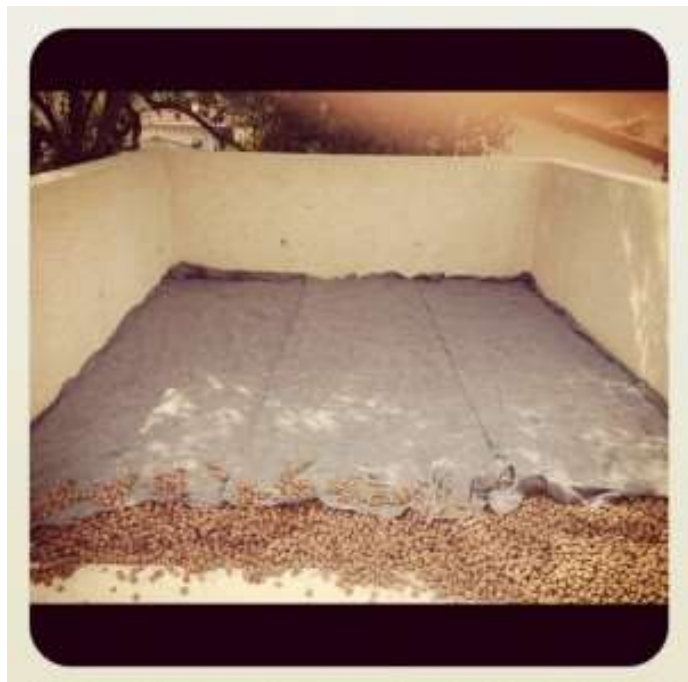

Fonte: Site Ecoeficientes - Especialistas em técnicas de Construção Sustentáveis (2021).

- $\quad 4^{\circ}$ passo: Membrana de proteção contra as raízes: a função desta membrana é controlar o crescimento das raízes da vegetação utilizada (Figura 11).

Figura 11: Membrana de Proteção.

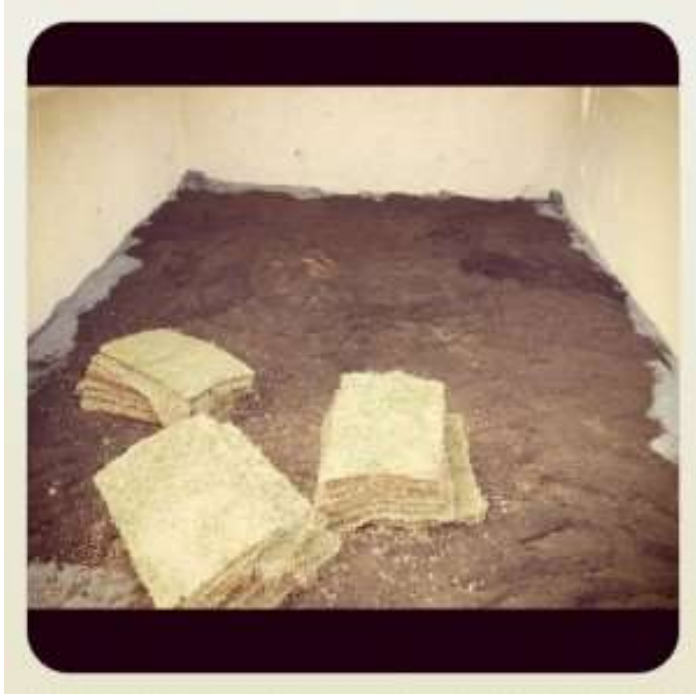

Fonte: Site Ecoeficientes - Especialistas em técnicas de Construção Sustentáveis (2021).

- $\quad 5^{\circ}$ passo: Substrato e solo (Figura 12). 
Figura 12: Estrutura do Telhado verde.

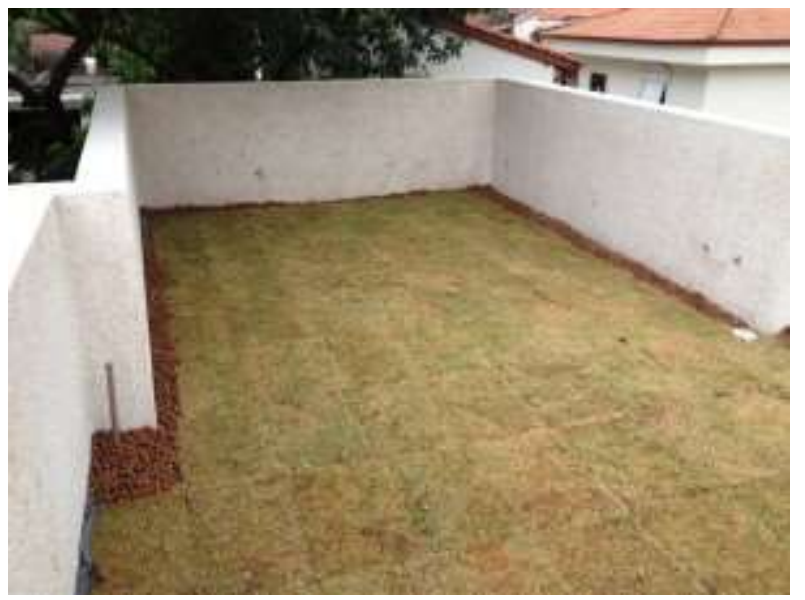

Fonte: Site Ecoeficientes - Especialistas em técnicas de Construção Sustentáveis (2021).

\section{- $6^{\circ}$ passo: Vegetação}

Segundo Pereira (2007) o sistema de Aplicação e Construção é dividido em aplicação contínua, com módulo préelaborada e aérea.

Contínua é um tipo de cobertura mais antiga, sendo o substrato distribuído imediatamente sobre a base impermeabilizada com as demais camadas.

Módulos pré-elaborados são feitos por empresas especializadas. Eles usam pequenas de bandejas rígidas, com substrato e vegetação já crescida e de manuseio fácil, são aplicáveis diretamente na construção através de encaixes e os resultados são imediatos.

Aérea caracteriza-se por não utilizar o substrato e em seu lugar uma tela que servirá como sustentação para apoiar a vegetação para seu crescimento. Uma vantagem quando se pensa para uso de plantas frutíferas como pepino, maxixe, maracujá e trepadeiras.

No estudo em questão a espécie escolhida pela empresa para a cobertura vegetal do Telhado Verde se trata da grama esmeralda (Zoysia japônica), uma das vantagens desse tipo de vegetação se deve ao seu efeito atapetado, sua baixa necessidade de poda, e apresentar resistência contra ervas daninhas. Além disso, é muito usada devido sua delicadeza e resistente às variações de nosso clima.

\subsection{Vantagens do uso de telhado verde}

Os telhados verdes têm a oportunidade de trazer a vegetação, onde antes não existia, melhorando a vida de toda a população urbana.

- Diminuição da poluição das cidades. A vegetação consome as substâncias tóxicas e a libera oxigênio na atmosfera.

- Combate o efeito de Ilhas de Calornas grandes cidades.

- Aumenta o isolamento térmico da edificação. Protege contra as altas temperaturas no verão e mantem a temperatura interna no inverno.

- Aumenta o isolamento acústico da edificação. A vegetação retém e isola ruídos.

- Proporciona maior retenção da água das chuvas. A vegetação ajuda na drenagem da água da chuva, diminuindo assim o escoamento de água e de sistemas de esgoto e ainda filtra a poluição dessas águas.

- Uma vez que retém melhor a água da chuva, diminui as possibilidades de enchentes.

- Auxilia na diminuição da temperaturados micro e macro ambientes externo. 
- Reduz a temperatura no ambiente interno, o que diminui a utilização de arrefecimento e o consumo de energia.

- As plantas atraem os pássaros, borboletas e entre outros aumentando a biodiversidade.

- Ajuda a enfeitar e embelezar as cidades. (Redação Sustentarqui, 2014)

\subsection{Desvantagens do uso do telhado verde}

- É necessário fazer manutenções frequentes para que a estrutura esteja sempre preservada.

- O projeto inicial dependendo do tipo de telhado pode ter um custo elevado.

- O tipo de vegetação possui diversas condicionantes quanto à estrutura, temperaturas e outras peculiaridades ambientais que podem dificultar o projeto.

- Um projeto de Telhado Verde é complexo e requer mão de obra qualificada.

- Se não houver uma manutenção especializada, podem aparecer pragas urbanas no telhado e seus benefícios tornam-se quase inválidos. (Redação Sustentarqui, 2014)

\section{Normas Vigentes}

A quantidade de normas em relação ao conforto térmico vem aumentando e se desenvolvendo cada vez mais devido as grandes mudanças climáticas e comportamento térmico, tendo em vista conforto e eficiência energética. Com esse aumento de demanda as normas surgiram para padronizar e estabelecer os requisitos térmicos dos ambientes diante das diversas situações existentes.

Para a realização deste trabalho foram selecionada as três organizações normalizadoras de destaque no mundo na área de desempenho e conforto térmico:

- $\quad$ ISO (InternationalOrganization for Standardization), entidade internacional com sede na Suíça, fundada em 1947, que congrega instituições normalizadoras de 170 países, dentre eles o Brasil. (ISO.ORG,acesso em 21 de maio de 2016);

- ASHRAE (American SocietyofHeating, Refrigerating, and Air ConditioningEngineers), fundada em 1894, a entidade deu origem pela fusão de duas instituições em 1959, e que, após a fusão, se denomina uma sociedade internacional de tecnologia da construção com mais de 54.000 membros. (ASHRAE.ORG, acesso em 21 de maio de 2016);

- ABNT (Associação Brasileira de Normas Técnicas), fundado em 1940 é responsável pela normalização técnica brasileira. A ABNT é o único representante da ISO no país. (ABNT.ORG, acesso em 21 de maio de 2016).

De acordo com a ISO (InternationalOrganization for Standardization), podemos destacar as seguintes normas regulamentadoras:

- $\quad$ ISO 7726 (1998) Ergonomics of the thermal environment-Instruments for measuring physical quantities.

- $\quad$ ISO 8996 (2004) - Ergonomics of the thermal environment -Determination of metabolic rate.

- ISO 7730 (2005) - Ergonomics of the thermal environment - Analytical determination and interpretation of thermal comfort using calculation of the PMV and PPD indices and local thermal comfort criteria.

- ISO 9920 (2007) - Ergonomics of the thermal environment - Estimation of thermal insulation and water vapour resistance of a clothing ensemble.

De acordo com a ASHRAE (American SocietyofHeating, Refrigerating, and Air ConditioningEngineers), a norma regulamentadora de maior destaque em relação ao conforto térmico é a seguinte:

- $\quad$ ASHRAE 55 (2013) Thermal Environmental Conditions for HumanOccupancy.

De acordo com a ABNT (Associação Brasileira de Normas Técnicas), podemos destacar as seguintes normas regulamentadoras:

- A NBR 15220/2005 - Desempenho térmico de edificações. 
- A NBR 15575/ 2013 - Edificações habitacionais - Desempenho - Esta norma entrou em vigor em 19 de julho de 2013, cancelando e substituindo sua primeira versão publicada em 2012.

- NR 17 - Esta Norma Regulamentadora visa a estabelecer parâmetros que permitam a adaptação das condições de trabalho às características psicofisiológicas dos trabalhadores, de modo a proporcionar um máximo de conforto, segurança e desempenho eficiente.

A norma regulamentadora $n^{\circ} 17$ tem como objetivo estabelecer os parâmetros que permitam a adaptação das condições de trabalho às características psicofisiológicas dos trabalhadores, de modo a proporcionar um máximo de conforto, segurança e desempenho eficiente.

De acordo, estabelece o subitem 17.1.2 da norma regulamentadora $\mathrm{n}^{\mathrm{o}}$ 17, para avaliar a adaptação das condições de trabalho às características psicofisiológicas dos trabalhadores, cabe ao empregador realizar a análise ergonômica do trabalho ou AET, devendo a mesma abordar, no mínimo, as condições de trabalho, conforme especifica a norma regulamentadora $n^{\circ} 17$.

A norma regulamentadora $\mathrm{n}^{\circ} 17$ apresenta a seguinte estrutura:

- Levantamento, transporte e descarga individual de materiais;

- Mobiliário dos postos de trabalho;

- Equipamentos dos postos de trabalho;

- Condições ambientais de trabalho e organização do trabalho.

\section{Metodologia}

O trabalho foi realizado na área urbana do município de Vazante localizada no Noroeste de Minas Gerais (Figura 13). A cidade está situada na mesorregião do noroeste de Minas. Sua extensão é de1.913 km², sendo que essa extensão se divide em três distritos, sendo eles: Claro de Minas, que fica localizada a $12 \mathrm{~km}$ da cidade de Vazante, e o de Vazamor, situada a $32 \mathrm{~km}$ da cidade. Na zona rural, tem aproximadamente 30comunidades, e três comunidades quilombolas (Bainha, Bagres e Cabeludo), sua localização fica a mais ou menos de $350 \mathrm{~km}$ de Brasília e $530 \mathrm{~km}$ de Belo Horizonte, a entrada principal do município é pela rodovia BR-040, além de outras, federais e estaduais. (Filho \& Viana 2011)

A cidade de Vazante apresenta intensa incidência solar, porém não foi localizada nenhuma residência com telhado verde, sendo detectado apenas numa empresa de mineração localizada no município, sendo que a mesma não será identificada.

Figura 13: Localização do Município de Vazante no mapa de Minas Gerais

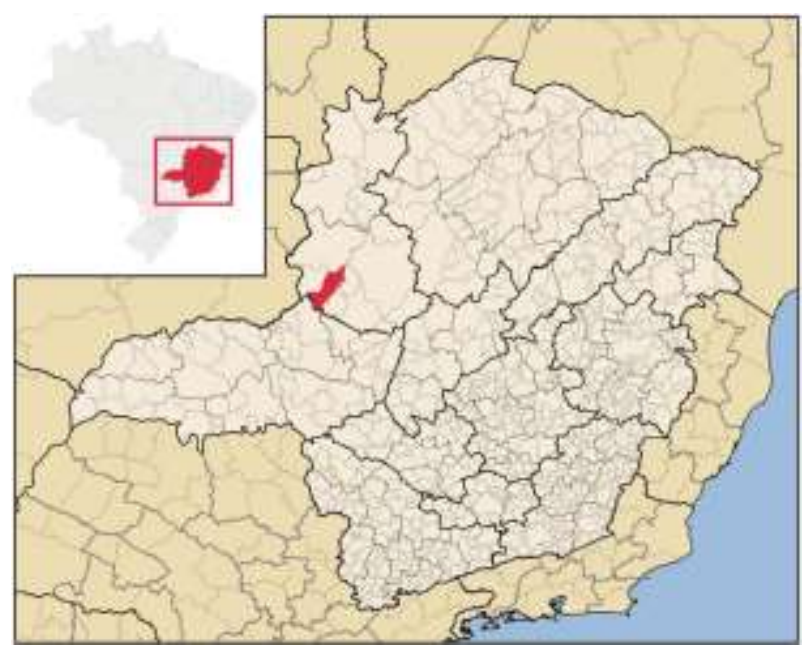

Fonte: Vazante.net (2021). 
Para a presente pesquisa optou-se em usar como suporte metodológico as diretrizes da Metodologia da pesquisa científica de Pereira et al. (2018). A metodologia é uma explicação cuidadosa, detalhada, precisa e exata de toda atividade desenvolvida no passo-a-passo do trabalho de pesquisa. Deve ajudar a explicar não só os produtos de investigação científica, como também seu próprio processo, pois suas exigências não são de submissão estrita a procedimentos rígidos, mas antes de produtividade na elaboração dos resultados. (Bruyne, 1989)

O processo de elaboração e execução da pesquisa para a presente monografia é fundamentado em levantamentos bibliográficos, estudo de caso e pesquisas documentais. Serão pesquisadas informações sobre a utilização do sistema construtivo, perante sua isolação térmica em construções que possuem ou não telhado verde, e quanto à sua economia.

A metodologia usada para o presente estudo foi um estudo de caso com caráter exploratório e quantitativo. Para tal foi realizada a leitura bibliográfica com análises em livros, teses, dissertações, monografias, manuais, artigos científicos, revistas, dentre outras fontes.

Pode-se dizer que os estudos e pesquisas feitos neste trabalho foram descritivos, sendo que relataram-se os ambientes com a intenção de mostrar o conforto satisfatório dos lugares de trabalho.

O objetivo da pesquisa descritiva é analisar, registrar, interpretar os fatos, sem que tenha modificação dos mesmos. Tem como papel analisar ou descobrir a frequência com que o fenômeno ocorre comparando as características em relação a outros fenômenos.

Em seguida, foi feito também um estudo de caso, de modo que falou-se das edificações para análises da temperatura e conforto térmicos das áreas em estudo.

O estudo de caso trata-se da coleta de dados relativo ao trabalho que se propôs a fazer, a fim de estudar as características, aspectos, detalhes e procedimentos que irão influenciar no desenvolvimento da pesquisa em si.

Para essa análise e observações foram utilizadas: normas regulamentadoras, livros, artigos, internet, e principalmente a edificação escolhida para a respectiva análise.

O foco da pesquisa será de maneira quantitativa, uma vez que se preocupará com representatividades numéricas, e não, com um maior aprofundamento da compreensão de um grupo social. (Collis \& Hussey, 2005)

Neste trabalho, a pesquisa qualitativa mostrou os níveis de conforto térmico das edificações para a análise de um ambiente de trabalho satisfatório.

Para realizar este trabalho foram feitas coletas de dados, medições in loco e visitas à edificação e verificação da estrutura física de todos os ambientes a ser analisada, verificação arquitetônica quanto ao posicionamento, à insolação e verificação do aproveitamento de recursos como ventilação natural e o sombreamento de fachadas, e com as medições de temperaturas e umidades em diferentes horários poderá analisar as cargas térmicas dos ambientes.

Tendo em vista o conforto térmico dos ambientes e através dos dados coletados foi possível obter tabelas e gráficos comparativos entre os dias de estudo de cada um dos locais. O local escolhido para a instalação do aparelho DataloggerUx 100-003 no ambiente interno foi o ponto central de cada uma das salas em estudo, e o DataloggerUx 100-023 externo foi instalado na parte externa da janela central de cada sala.

Foi utilizado para o levantamento de dados, aparelhos de medição de temperatura e umidade do ar Hobo Data Logger, fabricados pela organização ONSET Computer Corporation (Figura 14). 
Figura 14: Datalogger Ux100-003 / Temperatura E Umidade Relativa Do Ar

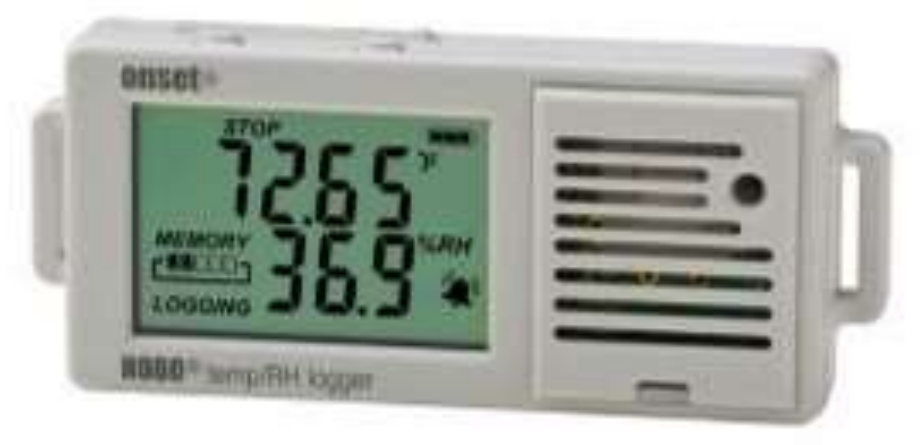

Fonte: Site ONSET Computer Corporation (2020).

Estes aparelhos capturam dados por um período pré-programado, tendo capacidade para armazenamento de 84650 leituras com intervalos de 1 segundo até 18 horas, com hora e data de início programáveis. (Corporation, 2016)

Os dados obtidos nas medições foram extraídos através do programa computacional Software - BHW - Pro. Depois estes dados serão inseridos no programa e este realizará a elaboração de gráficos que permitirão uma análise minuciosa das temperaturas em diferentes datas e horários.

Através dos resultados que foram obtidos podem-se analisar possíveis erros ou falhas e problemas do ambiente em relação ao conforto técnico e propor alternativas para solucioná-lo.

Os dados foram tabulados de acordo com as informações obtidas através dos equipamentos instalados nas salas com telhado verde e nas salas sem telado verde (parcela testemunha), para fins de comparação. O tempo de pesquisa foi durante o mês de agosto, uma vez que a empresa se disponibilizou somente neste período. Os dados foram coletados no período matutino e vespertino, por é o período onde a maior incidência solar e o horário em que os colaboradores da empresa estão exercendo suas atividades laborais.

\section{Resultados e Discussão}

Foram feitos dois gráficos para cada ambiente em estudo. Estes gráficos correspondem aos valores das temperaturas internas e externas, e umidade relativa do ar interno e externo medidos pelos aparelhos Dataloggers, fazendo o comparativo das salas que possui e das salas que não possui cobertura com telhado verde.

A análise foi feita nas 07 (sete) salas do primeiro pavimento da empresa, sendo que as salas 3 e 5 (figuras 15 a 17) não possui cobertura com telhado verde e as salas 9 e 10 (figuras 18 a 22), possuem cobertura com telhado verde. 
Figura 15: Temperatura e Umidade Datalogger, parte Externa, Sala 3, (parcela testemunha).

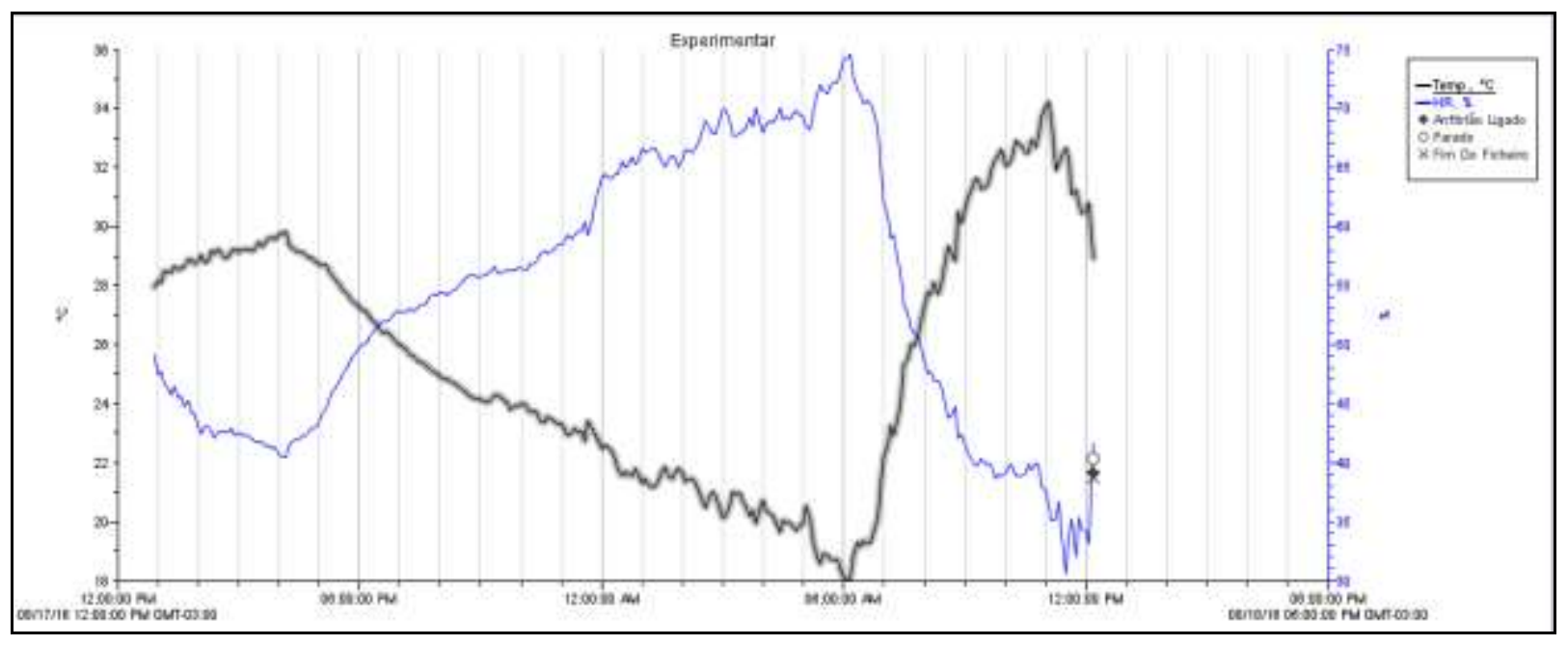

Fonte: Autores (2021).

Salienta-se que a umidade relativa do ar, como o próprio nome diz, não é um valor absoluto, depende diretamente da quantidade de vapor contido numa parcela de ar e, da temperatura do ar. Conforme aumenta a umidade absoluta no interior da parcela de ar, a umidade aumenta e, por outro lado, conforme aumenta a temperatura do ar, a umidade do ar diminui.

Como na sala em questão (parcela testemunha) não há controle dos efeitos causados pela temperatura e umidade por parte das plantas, observa-se uma grande variação nesses dois parâmetros ao longo do tempo. O Desvio-Padrão observado foi $25,50{ }^{\circ} \mathrm{C}$ para a temperatura e 53,90\% de umidade, em 280 amostras analisadas.

Figura 16: Temperatura e Umidade Datalogger, parte Interna, Sala 3, (parcela testemunha).

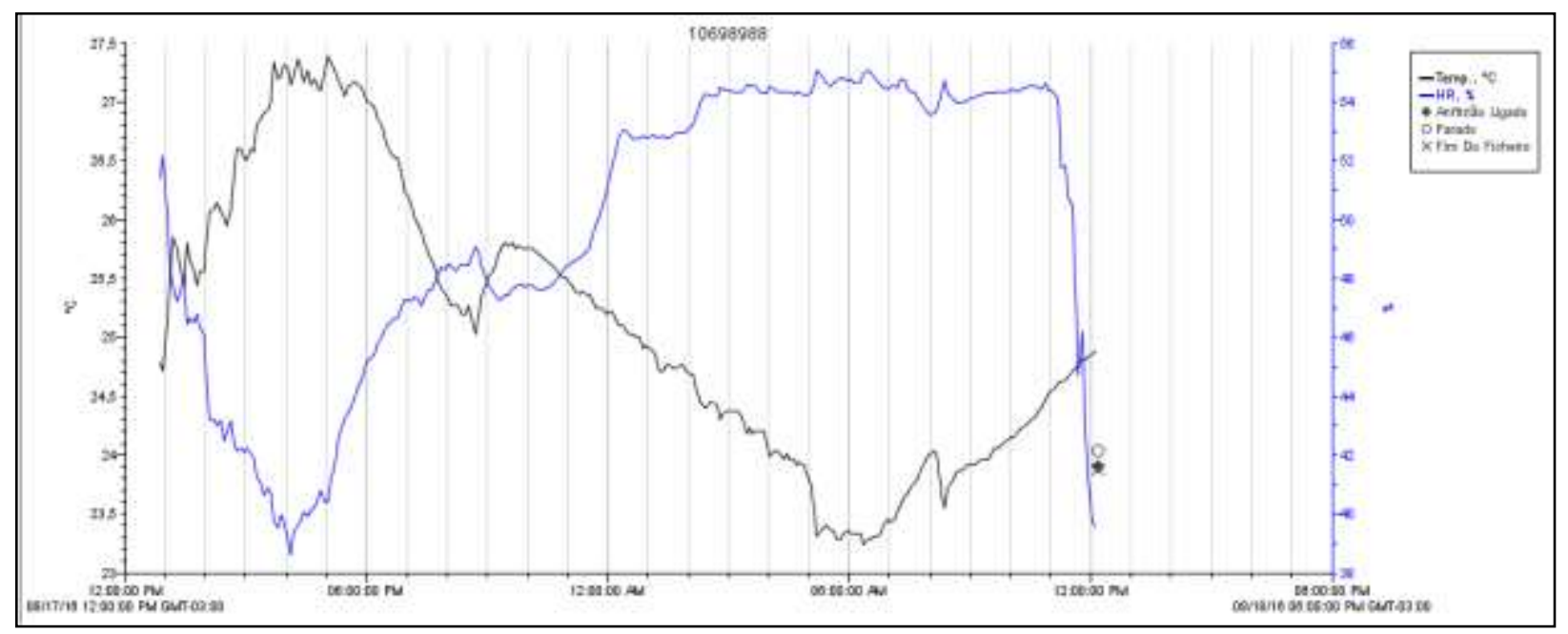

Fonte: Autores (2021).

Observa-se, através do gráfico, que ao se avaliar internamente a temperatura e umidade relativa do ar, comparativamente com a parte externa, houve um ligeiro acréscimo da temperatura mínima e decréscimo da umidade, mantendo o mesmo padrão de variação oposta, conforme relatado anteriormente. Isso decorre do aprisionamento do ar no interior da sala, funcionando como uma espécie de estufa. 
Research, Society and Development, v. 10, n. 14, e341101422238, 2021

(CC BY 4.0) | ISSN 2525-3409 | DOI: http://dx.doi.org/10.33448/rsd-v10i14.22238

Figura 17: Temperatura e Umidade Datalogger, parte Externa, Sala 5, não possui cobertura com telhado verde (parcela

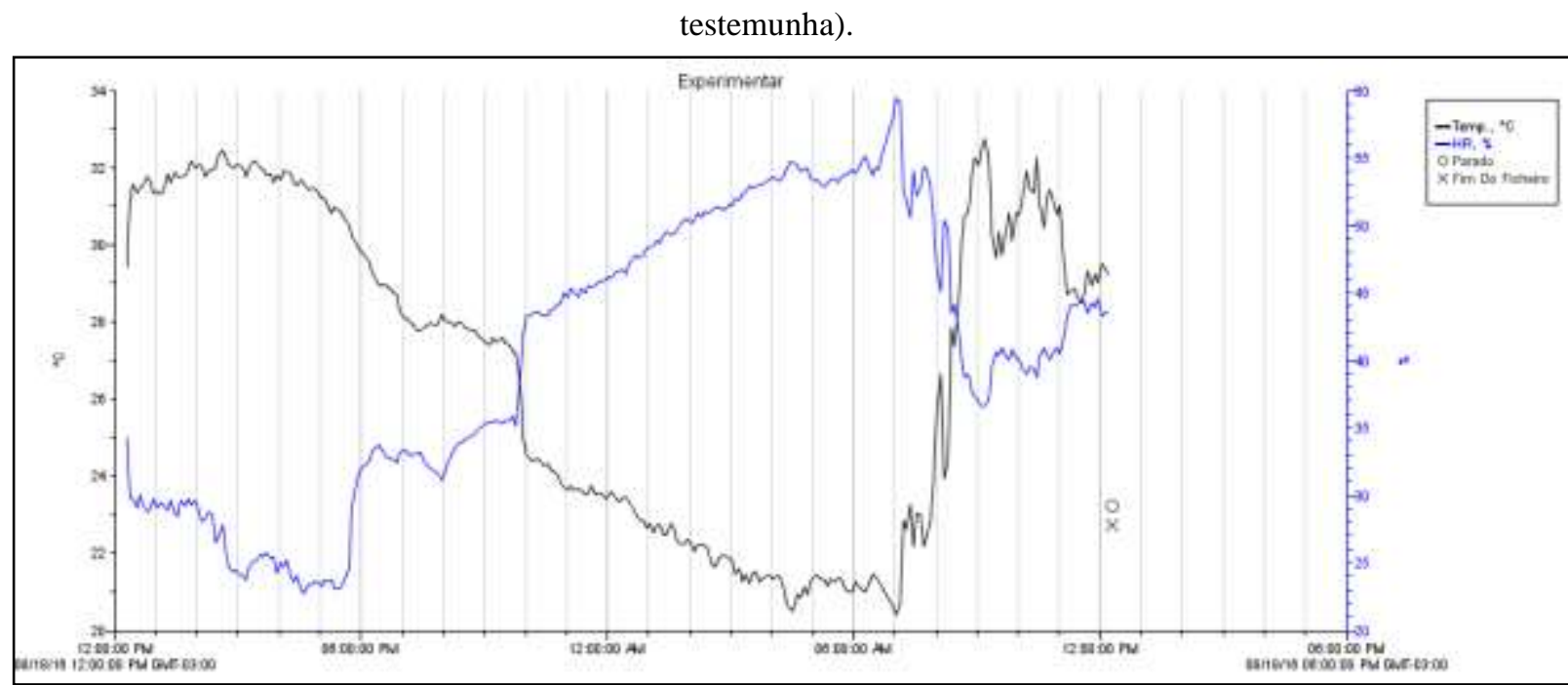

Fonte: Autores (2021).

Em relação à média da temperatura mais quente externa e interna, ela foi encontrada na sala 5 (figuras 17 e 18), onde não possui cobertura com telhado verde, o sol atinge a sala no período da manhã, com $26,80^{\circ} \mathrm{C}$ e $26,68^{\circ} \mathrm{C}$ respectivamente, apontando uma diferença de $0,12^{\circ} \mathrm{C}$. Os dados coletados foram em período que já haviam sendo realizadas atividades laborais nessa sala.

Figura 18: Temperatura e Umidade Datalogger, parte Interna, Sala 5, não possui cobertura com telhado verde.

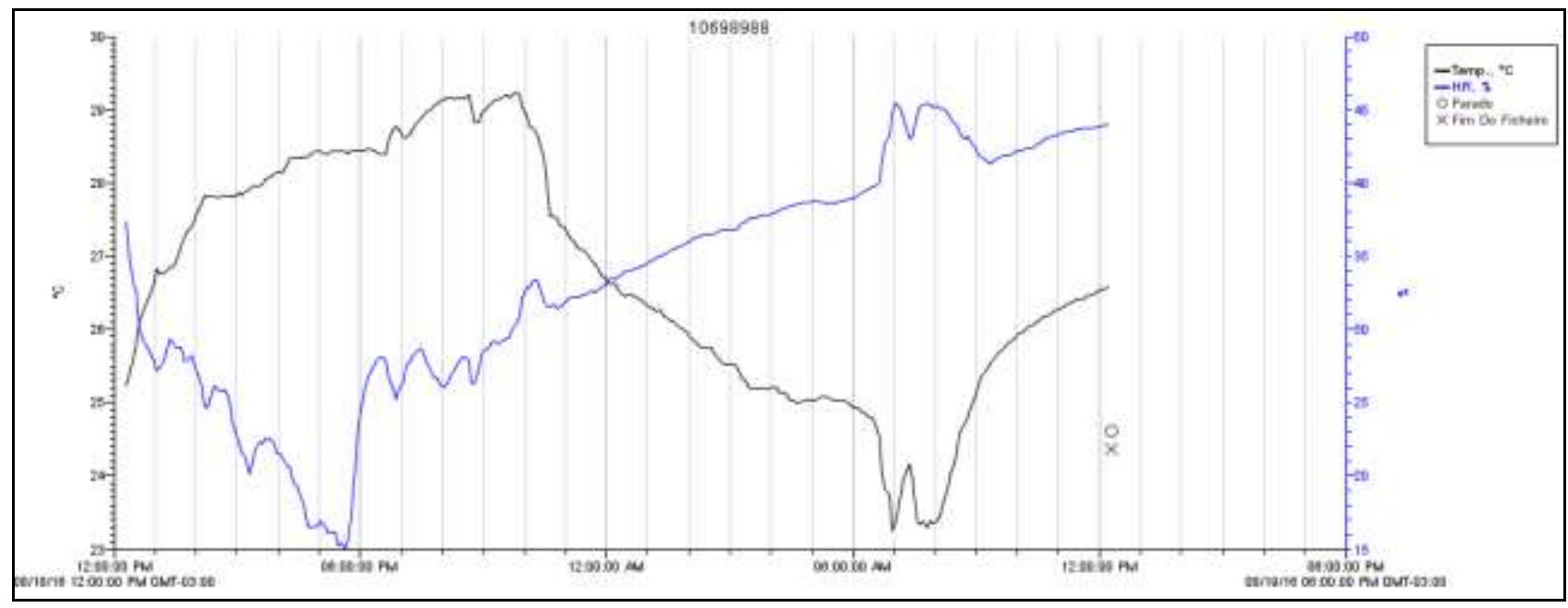

Fonte: Autores (2021). 
Figura 19: Temperatura e Umidade Datalogger, parte Externa, Sala 9, possui cobertura com telhado verde.

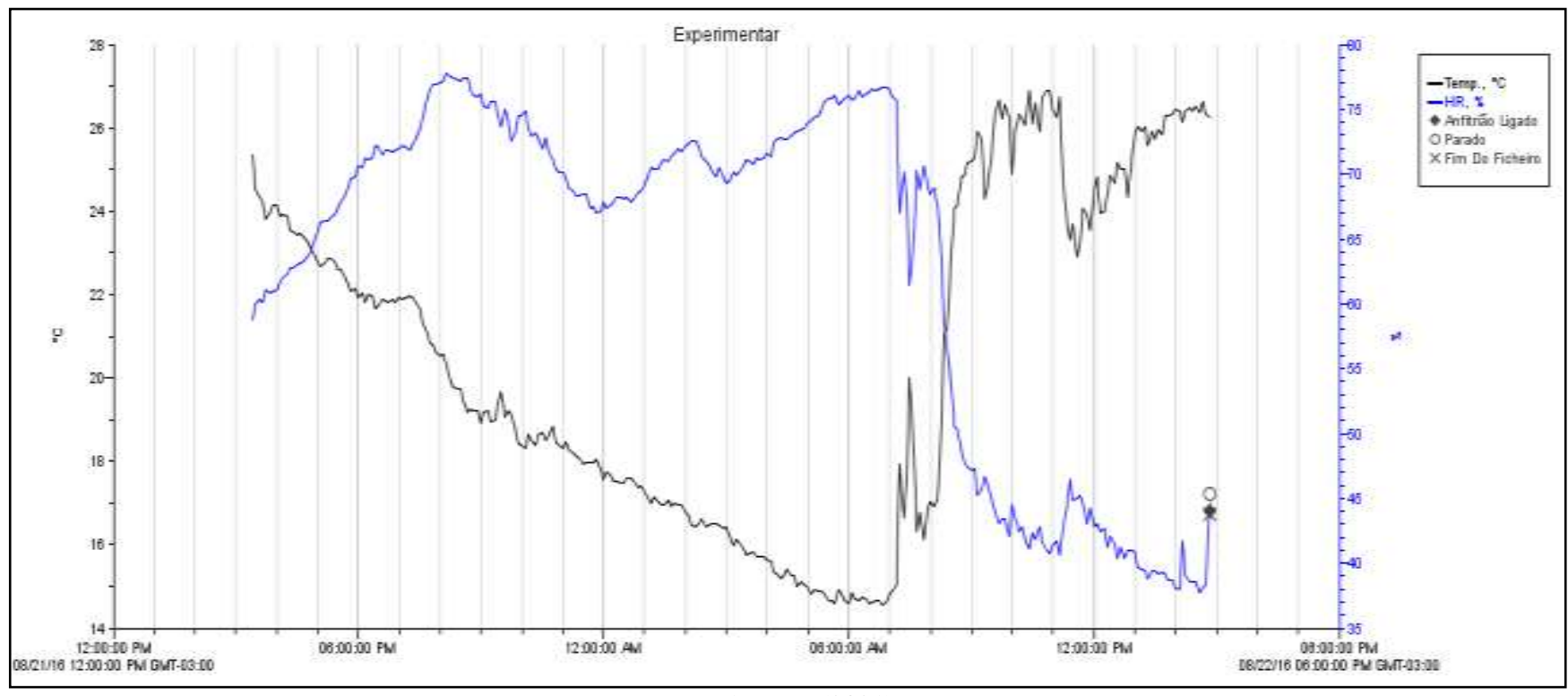

Fonte: Autores (2021).

Com relação à média da umidade máxima externa foi encontrada na sala 9 (figuras 19 e 20) com 63,09\%, contendo telhado verde e o sol atinge o ambiente no período da manhã. A média da umidade máxima interna foi encontrada na sala 10 com 52,78\%, contendo telhado verde e o sol atinge o ambiente no período da tarde.

Figura 20: Temperatura e Umidade Datalogger, parte Interna, Sala 9, possui cobertura com telhado verde.

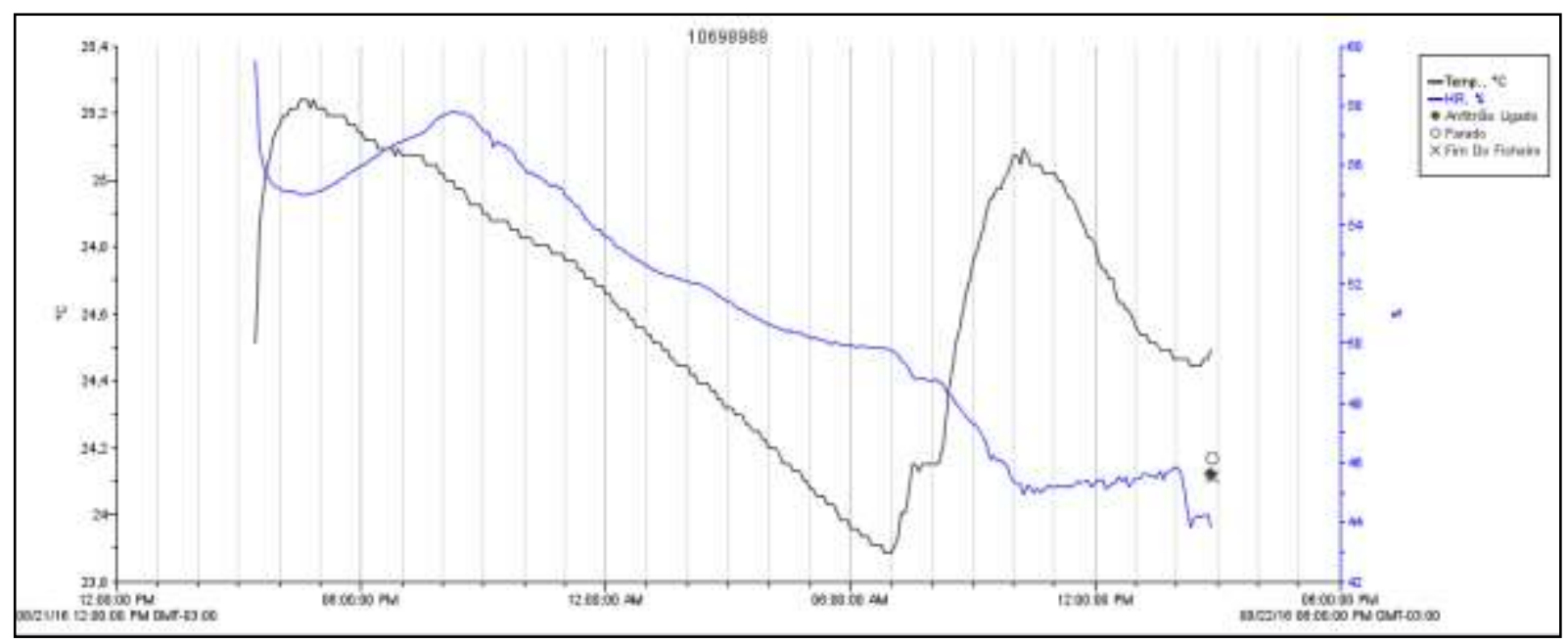

Fonte: Autores (2021).

Observando o gráfico contendo as temperaturas internas mais a temperatura externa, o telhado verde reduziu significativamente as temperaturas máximas durante o dia, como também demorou mais a esfriar durante a noite. É importante ressaltar que as paredes interferem no processo. Dessa forma, muito provavelmente em uma casa com paredes convencionais, a temperatura interna não se elevaria tanto durante o dia.

Em relação à umidade referente, observou-se que a umidade interna é mais permanente do que a umidade externa, no entanto consegue-se analisar que há uma grande alteração na umidade referente interna no instante em se começam as atividades laborais. Isso se dá devido, aos operários entrarem na sala e ligarem os ventiladores, que gera a umidade alterar automaticamente em companhia com sua presença dentro do ambiente de estudo. 
Figura 21: Temperatura e Umidade Datalogger, parte Externa, Sala 10, possui cobertura com telhado verde.

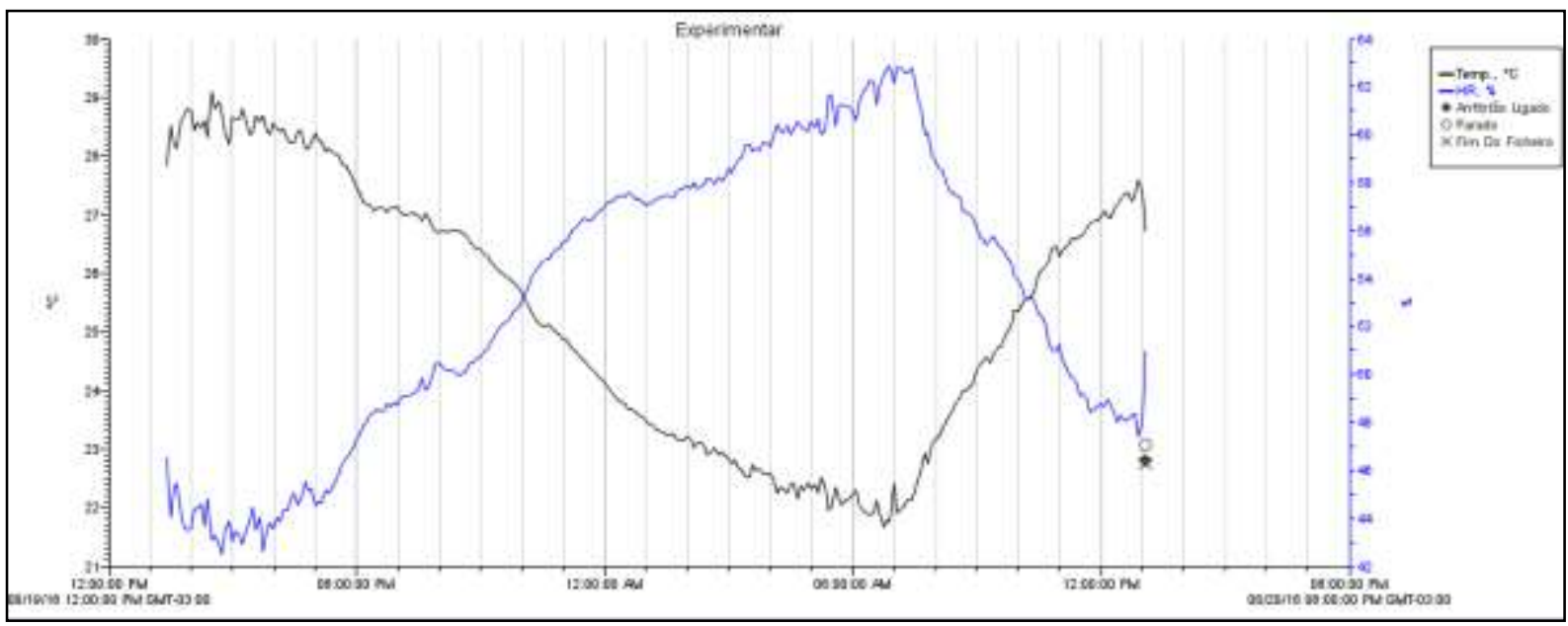

Fonte: Autores (2021).

Figura 22: Temperatura e Umidade Datalogger, parte Interna, Sala 10, possui cobertura com telhado verde.

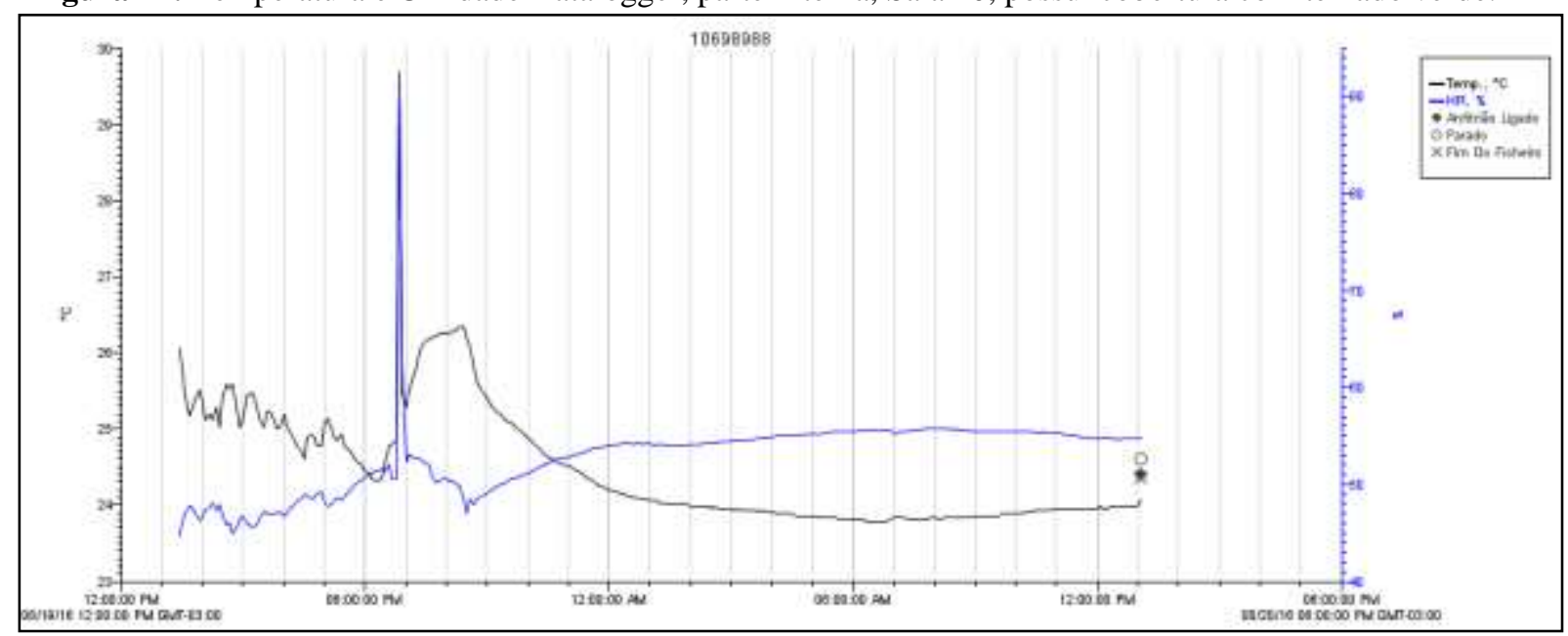

Fonte: Autores (2021).

Por meio dos gráficos de temperatura presentes nas figuras 21 e 22 constatamos que a temperatura interna se inicia sempre superior à externa e por toda a extensão do período da manhã elas se invertem. Essa alteração geralmente realiza-se no final da manhã e no princípio da tarde. E ao final da tarde e começo da noite elas invertem repetidamente. E observou que há qualquer estabilidade na temperatura interna da sala e uma alteração maior na temperatura externa, analisando-se assim um papel fundamental do edifício como protetor das circunstâncias externas de temperatura. 
Tabela 1: Médias de Estatísticas de Temperatura e Umidade Datalogger das salas que não possui cobertura com Telhado Verde.

\begin{tabular}{|c|c|c|c|c|}
\hline \multicolumn{5}{|c|}{$\begin{array}{l}\text { MÉDIAS DE TEMPERATURA E UMIDADE DAS SALAS QUE NÃO POSSUI COBERTURA COM } \\
\text { TELHADO VERDE }\end{array}$} \\
\hline & MÉDIA & MÉDIA & MÉDIA & MÉDIA \\
\hline SALAS & EXTERNA $\left({ }^{\circ} \mathbf{C}\right)$ & INTERNA $\left({ }^{\circ} \mathbf{C}\right)$ & EXTERNA (\%) & INTERNA (\%) \\
\hline 03 & 25,50 & 25,09 & 53,90 & 49,71 \\
\hline 05 & 26,80 & 26,68 & 40,42 & 33,29 \\
\hline $\begin{array}{l}\text { MÉDIA } \\
\text { GERAL }\end{array}$ & 26,15 & 25,89 & 47,16 & 41,50 \\
\hline
\end{tabular}

Fonte: Autores (2021).

Tabela 2: Médias de Estatísticas de Temperatura e Umidade Datalogger das salas que possui cobertura com Telhado Verde.

\begin{tabular}{|c|c|c|c|c|}
\hline $\begin{array}{l}\text { MÉDIAS I } \\
\text { TELHADO }\end{array}$ & $\begin{array}{l}\text { TEMPERATUR } \\
\text { ERDE }\end{array}$ & UMIDADE DA & AS QUE POS & COBERTURA \\
\hline & MÉDIA & MÉDIA & MÉDIA & MÉDIA \\
\hline SALAS & EXTERNA $\left({ }^{\circ} \mathbf{C}\right)$ & INTERNA $\left({ }^{\circ} \mathrm{C}\right)$ & EXTERNA (\%) & INTERNA (\%) \\
\hline 09 & 20,44 & 24,65 & 63,09 & 51,30 \\
\hline 10 & 25,30 & 24,48 & 53,13 & 52,78 \\
\hline $\begin{array}{l}\text { MÉDIA } \\
\text { GERAL }\end{array}$ & 22,87 & 24,56 & 58,11 & 52,04 \\
\hline
\end{tabular}

Fonte: Autores (2021).

Em relação à média da temperatura mais fria externa e interna, ela foi encontrada na sala 09, onde possui cobertura com telhado verde, o sol atinge a sala no período da tarde e na sala não havia turnos de trabalho, $\operatorname{com} 20,44^{\circ} \mathrm{C}$ e $24,65^{\circ} \mathrm{C}$ respectivamente (Tabela 1 ).

Em relação à média de umidade mínima externa, foi encontrada na sala 10 com 53,13\%, e a média de umidade mínima interna 51,30\% com uma diferença de $1,83 \%$. Essa sala possui cobertura com telhado verde e o sol atinge o ambiente no período da manhã (Tabela 2).

De acordo com o pesquisador Victor Olgyay (2006), a zona de conforto da umidade relativa varia entre $20 \%$ a $80 \%$, enquanto a temperatura varia entre $18^{\circ} \mathrm{C}$ a $29^{\circ} \mathrm{C}$, e ainda se mantém confortável. Observou-se então que as salas que possui cobertura com telhado verde se mantem mais confortável quanto à umidade relativa e a temperatura do que as salas que não possui cobertura com telhado verde, sendo que a temperatura das salas que possui cobertura com telhado verde teve uma média de $22,87^{\circ} \mathrm{C}$ e $24,56^{\circ} \mathrm{C}$, parte externa e interna respectivamente, e a umidade relativa teve uma média de $58,11 \%$ e $52,04 \%$, parte externa e interna respectivamente. Enquanto isso, as salas que não possui telhado verde tiveram uma média de $26,15^{\circ} \mathrm{C}$ e $25,89^{\circ} \mathrm{C}$, parte externa e interna respectivamente, e a umidade relativa teve uma média de $47,16 \%$ e $41,50 \%$, parte externa e interna respectivamente. Pode-se observar então que em relação ao uso de cobertura com telhado verde a temperatura teve uma redução média de $3,28^{\circ} \mathrm{C}$ na parte externa e $1,33^{\circ} \mathrm{C}$ na parte interna das salas. Já em relação a umidade relativa, o uso de cobertura com telhado verde aumentou em 10,95\% na parte externa e 10,54\% na parte interna das salas. Observa-se ainda que quanto menor a temperatura maior a umidade do ambiente. 


\section{Conclusão}

Notou-se através das médias coletadas que os níveis não acarretam desconforto térmico para os ambientes de acordo com o método de Victor Olgyay.

A empresa conta com um projeto arquitetônico que apresenta uma estrutura que atendem as expectativas em relação ao conforto térmico dos ambientes de estudo, as construções apresentam brises de alvenaria na vertical diante das fachadas que diminuem razoavelmente a temperatura dentro dos ambientes propiciando assim temperaturas internas mais brandas.

Portanto pelos resultados obtidos com as médias gerais das temperaturas dentro dos ambientes em estudo, é possível verificar que as temperaturas foram em torno dos $24,58^{\circ} \mathrm{C}$ onde possui cobertura com telhado verde e $25,89^{\circ} \mathrm{C}$ onde não possui cobertura com telhado verde, sendo assim, os dois casos está dentro do limite máximo que é de $29^{\circ} \mathrm{C}$.

De acordo com a NR17 para os locais de trabalho onde são executadas atividades que exijam solicitação intelectual e atenção constantes, tais como: salas de controle, laboratórios, escritórios, salas de desenvolvimento ou análise de projetos, dentre outros, os níveis de temperatura devem variar entre $20^{\circ} \mathrm{C}$ e $23^{\circ} \mathrm{C}$. Ou seja, mesmo com a presença do telhado verde ainda sim seria necessário a redução da temperatura das salas, e como alternativa para solucionar o problema seria a instalação de brises nas janelas com inclinação de $45^{\circ}$, impedindo assim a incidência direta da radiação solar sobre interior das salas, de forma a evitar o aquecimento excessivo.

Com relação aos benefícios econômicos, os telhados verdes reduzem a variação térmica da estrutura, e da edificação como um todo, reduzindo expressivamente os custos com aquecimento e resfriamento da edificação, contribuindo assim para a eficiência energética da edificação.

\section{Referências}

ABNT. (2021). Associação Brasileira de Normas Técnicas. http://www.abnt.org.br/.

Aqui, Sustentar. Vantagens e desvantagens do telhado verde. http://sustentarqui.com.br/dicas/vantagens-e-desvantagens-de-um-telhado-verde/.

Araújo, S. R. (2007). As funções dos telhados verdes no meio urbano, na gestão e no planejamento de recursos hídricos. Soropédica, RJ. p.5.

Ashrae.Org, American Society of Heating Refrigerating and Airconditioning Engineers. https://www.ashrae.org/about-ashrae.

Awebic. Telhado verde, Lei em Paris. (2016). http://awebic.com/cultura/lei-obriga-que-empresas-de-paris-facam-sua-parte-para-preservar-o-meio-ambiente/.

Bruyne. (1989). A Research methods and organization studies. London: Unwin Hyman.

Carvalho, D., Sartorato, E. \& Carneiro, R. (2004). Introdução. http://pesquisabibliografica.vilabol.uol.com.br/introducao.htm.

Criativos, Telhados. Origem dos Telhados Verdes. (2012). http://telhadoscriativos.blogspot.com.br/2012/03/origem-dos-telhados-verdes.html.

Collis, J. \& Hussey, R. (2005). Um guia prático para alunos de graduação e pós-graduação. Revisão Técnica, 2 (5), 1-9.

Corporation, Onset Computer. AparelhoDataLogger. vendas@onsetbrasil.com.br.

Corsini, R. (2011). Telhado verde. Infraestrutura urbana. http://infraestruturaurbana.pini.com.br/solucoes-tecnicas/16/1-telhado-verdecobertura-deedificacoes-com-vegetacao-requer-260593-1.aspx.

Cordeiro, J. \& Spturis. Prédio Prefeitura de São Paulo. http://www.cidadedesaopaulo.com/sp/br/o-que-visitar/pontos-turisticos/230-vale-do-anhangabau.

Denzin, N. K. \& Lincoln, Y. S. (2000). Handbook of qualitative research. Thousand Oaks. 16 (2) 98.

Discovery, Channel. (2009). As Sete Maravilhas da Antiguidade.

Ecoeficientes. (2021). O que é e como fazer um telhado verde. http://www.ecoeficientes.com.br/o-que-e-e-como-fazer-um-telhado-verde/.

Green Roof Service. (2010). Green Roof Service LLC. http://www.greenroofservice.com/.

Herlemann, J. (2012). Análise do conforto ambiental em salas de aula: comparação entre dados técnicos e a percepção do usuário. Estruturas e Construção Civil, Universidade Federal de Goiás.

História e Arquitetura. (2013). O Telhado Verde de Lecorbusier. http://historiaearquitetura.blogspot.com.br/2013/10/o-telhado-verde-de-le-corbusier.html

Ingra. (2010). Internacional Green RoofsAssociation. A Quick Guide to Grenn Roofs. http://www.igra-world.com/. 
Research, Society and Development, v. 10, n. 14, e341101422238, 2021

(CC BY 4.0) | ISSN 2525-3409 | DOI: http://dx.doi.org/10.33448/rsd-v10i14.22238

Iso.Org. Internacional Organization For Standartization. http://www.iso.org/iso/home/about.htm.

Kowaltowski, D. C. C. K. (2011). Arquitetura Escolar: o projeto do ambiente de ensino. Oficina de textos. 10 (4), 1-9.

Lamberts, R., Dutra, L \& Pereira, F. O. R. (2004). Eficiência energética na arquitetura. PW Gráficos, São Paulo, 21(1), p. 103-112.

Mascaró, L. R. de. (1985). Energia na Edificação: estratégia para minimizar o seu consumo. Parma Ltda, São Paulo, 14(40), 225-243.

Mendes, Oro. (2015). Lei obriga que empresas de Paris façam a sua parte para preservar o meio ambiente. http://awebic.com/cultura/lei-obriga-queempresas-de-paris-facam-sua-parte-para-preservar-o-meio-ambiente/.

Morais. C. S. (2004). Desempenho Térmico de Coberturas Vegetais em Edificações na Cidade de São Carlos/SP. Programa de Pós Graduação em Engenharia Civil da universidade Federal de São Carlos.

Brasil. NR 17. Norma Regulamentadora 17. http://www.guiatrabalhista.com.br/legislacao/nr/nr17.htm.

Oliveira, M. (2011). Conforto ambiental ou conforto térmico? http://www.forumdaconstrucao.com.br/conteudo.php?a=4\&Cod=935.

Oliveira, S. L. (2002). Tratado de metodologia científica. Pioneira Thomson Learning, 8(3), 692-712.

Pereira A. S. et al. (2018). Metodologia da pesquisa científica. [free e-book]. Santa Maria/RS. Ed. UAB/NTE/UFSM.

Pereira. M. F. (2007). Teto verde: o uso de coberturas vegetais em edificações. 12(3), 1-11.

Olgyay, V. (1963). Design withclimate. Princeton, Universidade de Princenton. 236 p.

Olgyay, V. (2006): Arquitetura y clima manual de disenoboclimático para arquitectos y urbanistas. Barcelona, Editorial Gustavo Gili, 203 p.

Souza, L. C. L. (1990). Desempenho térmico de coberturas leves: Aplicação do modelo NBSL. Departamento de Arquitetura e Urbanismo da Escola de Engenharia de São Carlos da universidade de São Paulo.

Sustentavel, Construindo. Conforto ambiental. 9(2), 1. http://construindosustentavel.blogspot.com.br/2011/01/conforto-ambiental.html.

Tomaz, (2005). Telhado verde. BMPs. 39(2), 4. 